Uranium Mill Tailing Remedial Action Project

\title{
Environmental Assessment of Ground-Water Compliance Activities At the Uranium Mill Tailings Site Spook, Wyoming
}

February 1997

Prepared by

U.S. Department of Energy Albuquerque Operations Office Grand Junction Office

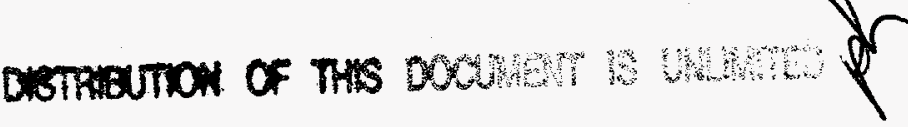

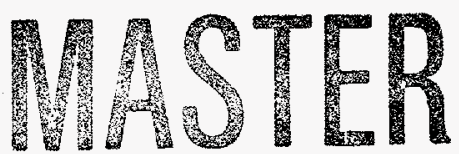


This page intentionally blank 


\section{DISCLAMMIRR}

Portions of this document may be illegible in electronic image products. Images are produced from the best available original document. 


\section{DISCLAIMER}

This report was prepared as an account of work sponsored by an agency of the United States Government. Neither the United States Government nor any agency thereof, nor any of their employees, make any warranty, express or implied, or assumes any legal liability or responsibility for the accuracy, completeness, or usefulness of any information, apparatus, product, or process disclosed, or represents that its use would not infringe privately owned rights. Reference herein to any specific commercial product, process, or service by trade name, trademark, manufacturer, or otherwise does not necessarily constitute or imply its endorsement, recommendation, or favoring by the United States Government or any agency thereof. The views and opinions of authors expressed herein do not necessarily state or reflect those of the United States Government or any agency thereof. 


\section{Contents}

Page

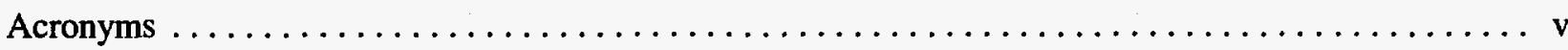

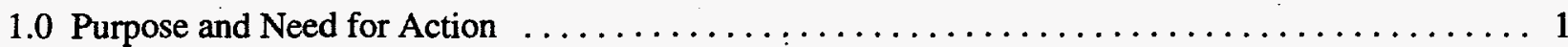

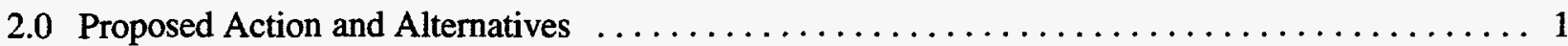

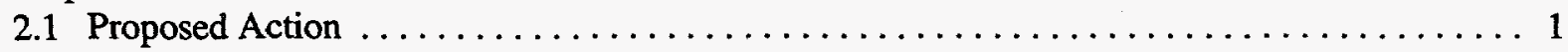

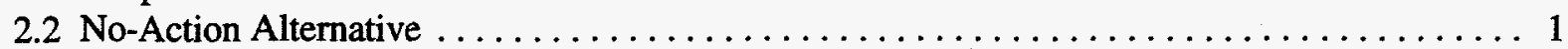

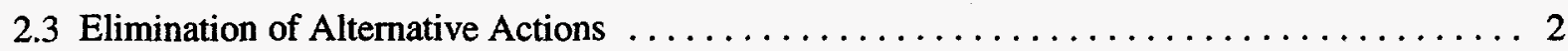

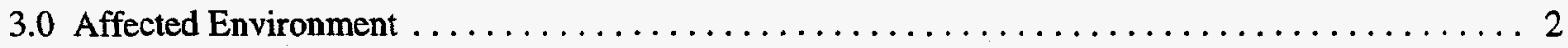

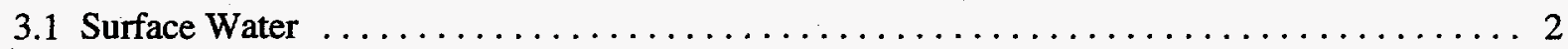

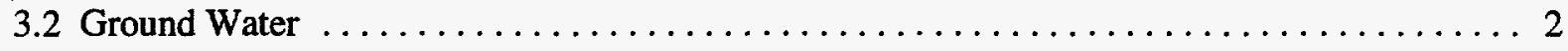

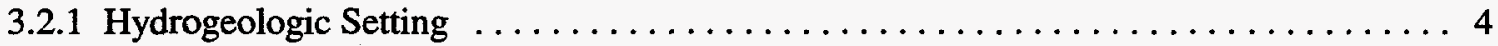

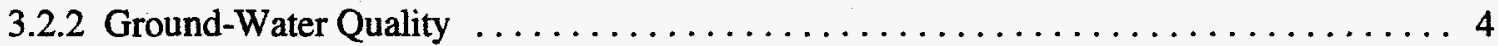

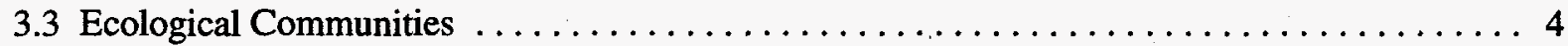

3.4 Land Use/Population $\ldots \ldots \ldots \ldots \ldots \ldots \ldots \ldots \ldots \ldots \ldots \ldots \ldots \ldots \ldots \ldots \ldots$

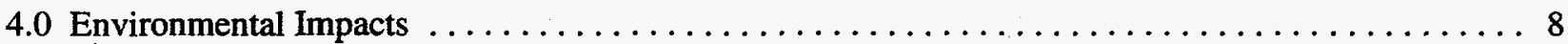

4.1 Impacts From Proposed Action $\ldots \ldots \ldots \ldots \ldots \ldots \ldots \ldots \ldots \ldots \ldots \ldots \ldots \ldots \ldots \ldots$

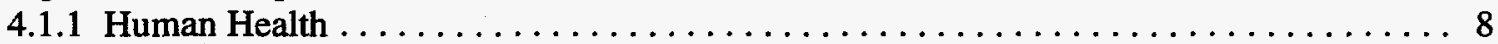

4.1.2 Surface Water . . . . . . . . . . . . . . . . . . . . . 9

4.1 .3 Ground Water . . . . . . . . . . . . . . . . . . . . . . . . . . 9

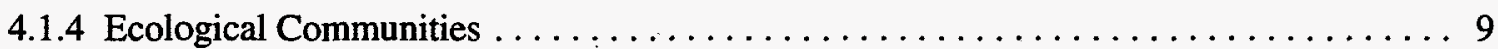

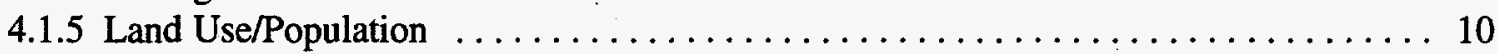

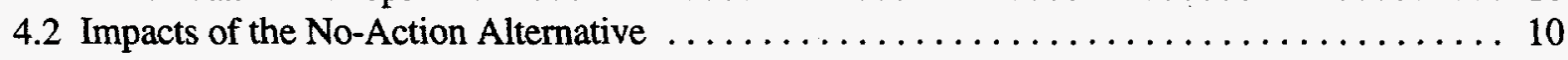

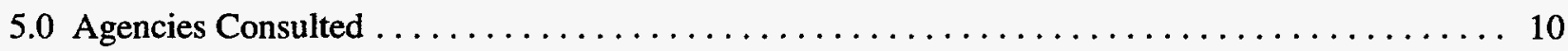

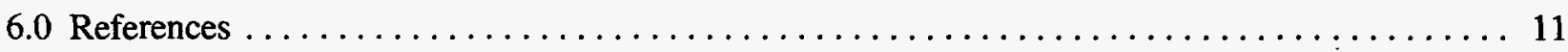

\section{Appendix}

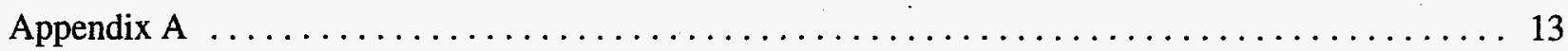

\section{Figure}

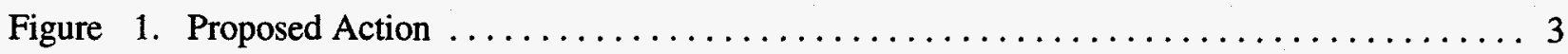

2. Location and Hydrogeology, Spook, Wyoming, Site $\ldots \ldots \ldots \ldots \ldots \ldots \ldots \ldots \ldots$

\section{Table}

Table 1. Upper Sandstone Unit Ground-Water Quality Near the Spook, Wyoming, Site . . . . . . 7 
This page intentionally blank 


\section{Acronyms}

DOE U.S. Department of Energy

EPA U.S. Environmental Protection Agency

NRC U.S. Nuclear Regulatory Commission

PEIS Programmatic Environmental Impact Statement

RAP Remedial Action Plan

SOWP Site Observational Work Plan

UMTRA Uranium Mill Tailings Remedial Action 
This page intentionally blank 


\subsection{Purpose and Need for Action}

The purpose of the Uranium Mill Tailings Remedial Action (UMTRA) Ground-Water Project is to protect human health and the environment at abandoned mill processing sites by complying with U.S.

Environmental Protection Agency (EPA) ground-water standards set forth in Title 40 of the U.S. Code of Federal Regulations, Part 192 (40 CFR 192). The U.S. Department of Energy (DOE) proposes compliance with EPA standards at the Spook, Wyoming, UMTRA site by using the selected alternative stated in the Final Programmatic Environmental Impact Statement (PEIS) for the Uranium Mill Tailings Remedial Action Ground Water Project (DOE 1996). The proposed action establishes the framework for determining the appropriate ground-water compliance strategy at each UMTRA site.

\subsection{Proposed Action and Alternatives}

\subsection{Proposed Action}

On the basis of limited-use ground water, ${ }^{*}$ the proposed action at the Spook site is application for supplemental standards. This action is consistent with the framework used to select the appropriate compliance strategy set forth in the Proposed Action (Section 2.1) of the PEIS. The proposal to apply supplemental standards is supported by the Risk Analysis (Appendix F) of the Site Observational Work Plan (SOWP) for the UMTRA Project Site at Spook, Wyoming (DOE 1995). In summary, the results of the Risk Analysis support the proposed compliance strategy of no further remediation based on application for supplemental standards. The affected ground water from the uppermost aquifer at the site poses no risk to human health and the environment because of the absence of relevant or realistic exposure pathways. The screening-level risk analysis for background ground water from the uppermost aquifer demonstrates that naturally occurring concentrations of selenium and uranium in the ground water would cause unacceptable risks to humans, and is not recommended for use for livestock or irrigation.

The Nuclear Regulatory Commission (NRC) concurs with the DOE proposal (NRC 1996) to apply supplemental standards at the Spook, Wyoming, site (see Appendix A).

By applying supplemental standards, no additional site activities (including ground-water monitoring, characterization, or institutional controls) would be required.

\subsection{No-Action Alternative}

DOE requires that an environmental assessment evaluate the no-action alternative. The evaluation would provide an environmental baseline for comparing the impacts of the proposed action (10 CFR 1021.321[c]). Under the no-action alternative, certain regulatory requirements would not be met. No further documentation of compliance with EPA standards would be provided, and public, State, and NRC participation in the DOE decision-making process would cease.

*40 CFR 192.11(c) defines limited-use ground water as ground water that is not a current or potential source of drinking water...Ambient contamination not due to activities involving residual radioactive materials from a designated processing site exists that can not be cleaned up using treatment methods reasonably employed in public water systems. 


\subsection{Elimination of Alternative Actions}

Because the contaminated ground water at the Spook site qualifies for supplemental standards and the lack of a ground-water pathway will not pose a risk to human health or the environment, natural flushing and active remediation methods were considered but eliminated from further analysis in this environmental assessment. The logical framework for making this determination was evaluated in the PEIS as illustrated in Figure 1.

\subsection{Affected Environment}

Section 3.2.22 of the PEIS provides a general description of the affected Spook site environment. Resources that have the potential to be affected at the site are surface water, ground water, ecological systems, and land use. The contaminated ground water in the uppermost aquifer could potentially affect these resources. Because the proposed action requires no further site activities, air quality, wildlife habitat, plant species, noise, and visual and cultural resources are not expected to be affected. Furthermore, public health and safety, transportation, employment, utility usage, and energy resources in the vicinity of the site are not expected to be affected. The population in the site vicinity is sparse, and there are no disproportionately high populations of minor or low-income individuals.

\subsection{Surface Water}

The Spook site is located between two unnamed east and southeast trending ephemeral drainages that are tributaries of the Dry Fork of the Cheyenne River. The Dry Fork is approximately one mile (mi) (1.6 kilometers $[\mathrm{km}]$ ) south of the site. The elevation in the area of the site is approximately 4,990 feet (ft) $(1,520$ meters $[\mathrm{m}])$ above mean sea level. The Dry Fork drainage area is approximately 140 square miles (360 square $\mathrm{km}$ ) and empties into the Cheyenne River approximately $40 \mathrm{mi}(64 \mathrm{~km}$ ) from the site. Information from a U.S. Geological Survey gauging station in the Dry Fork area shows that water flow ranges from 0 to 3.45 cubic feet per second ( 0.1 cubic meter per second). The Dry Fork has extended periods of no flow, particularly in winter and late summer. Water in the shallow alluvium of the Dry Fork is relatively close to the surface even during no-flow periods, as evidenced by the dense growth of riparian vegetation and scattered wetlands in the streambed.

Field observations and interviews with local ranchers indicate no direct evidence of ground-water discharge from the upper sandstone unit to the surface or to surface water near the Spook site (DOE 1990).

\subsection{Ground Water}

The SOWP (DOE 1995) and the Remedial Action Plan (RAP) and Site Conceptual Design for Stabilization of the Inactive Uranium Mill Tailings Site at Spook, Wyoming (DOE 1990), describe the most probable ground-water conditions at the Spook site. The assessment of the interaction of site-related constituents with the environmental setting, constituent release mechanisms, contaminant fate and transport, and potential risks to human health and the environment was based on these descriptions. The proposed action is based on this assessment.

Site characterization was based on data collected through 1988. These data were used as the basis for surface remediation as documented in the RAP. The NRC, DOE, and the State of Wyoming have agreed that no further ground-water monitoring is required. 
Box 1

Characterize plume and hydrological condition using existing data and new data as required.

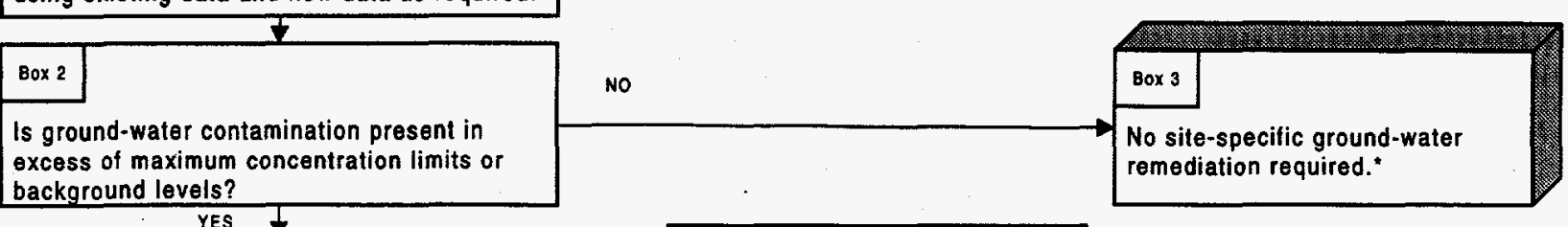

Box 4
$\begin{aligned} & \text { Does contaminated ground water qualify for } \\ & \text { supplemental standards due to limited-use } \\ & \text { ground water? }\end{aligned}$

ground water?
Dox 6
Does contaminated ground water qualify for
alternate concentration limits based on
risks and other factors?
riss able human health and environmental
\begin{tabular}{|l|}
\hline Box 8 \\
\hline Does contaminated ground water qualify for \\
supplemental standards due to excessive
\end{tabular} environmental harm from remediation?

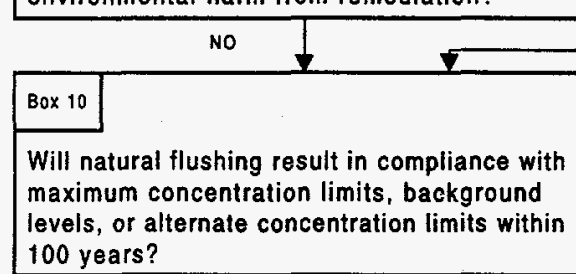
100 years?
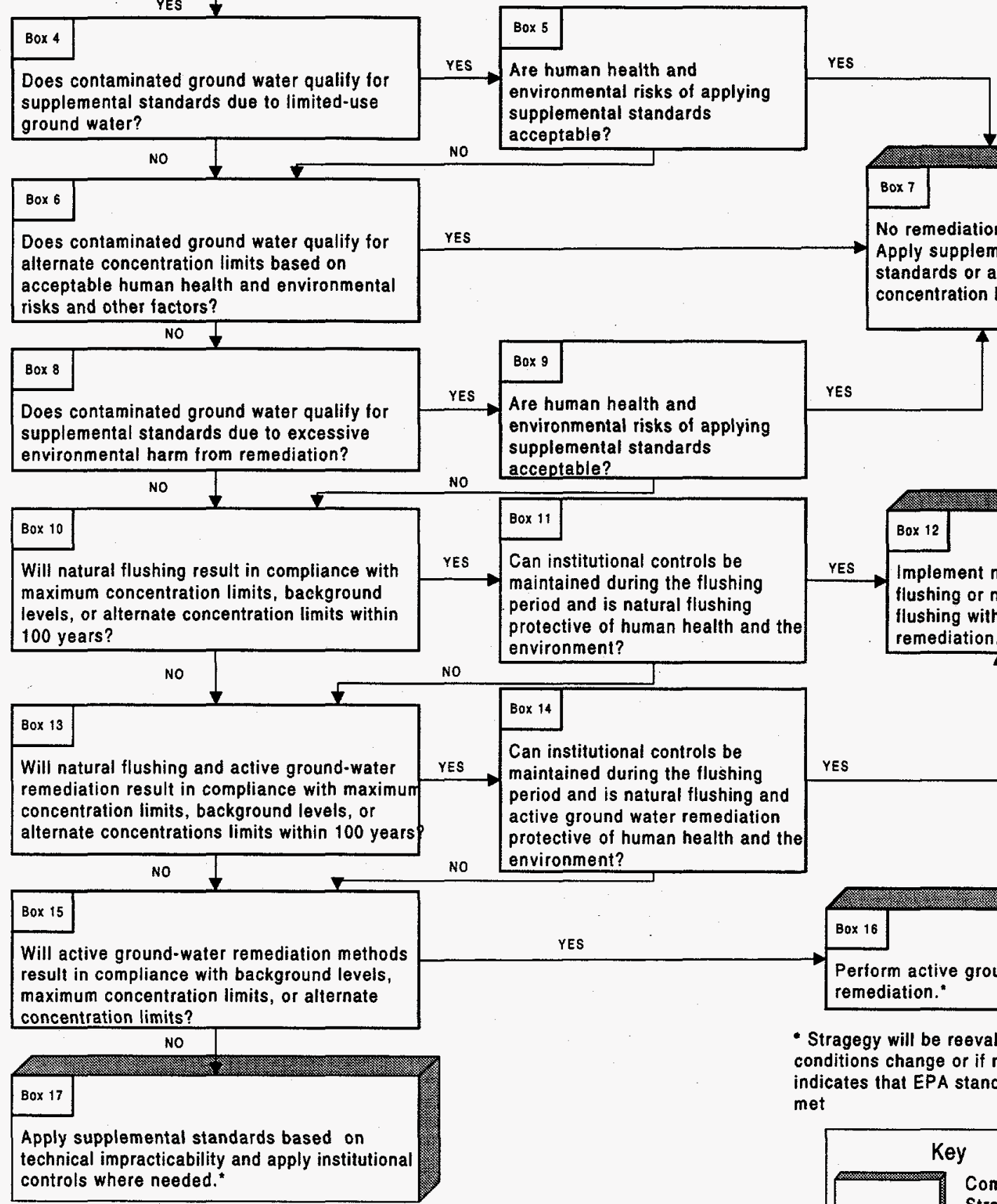

\section{$80 \times 7$}

No remediation required.

Apply supplemental standards or alternate concentration limits.

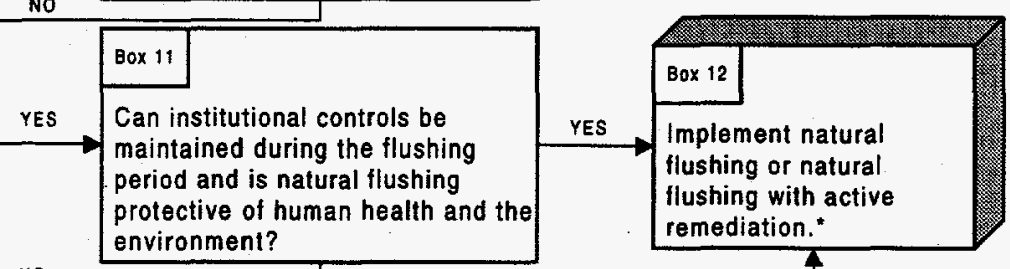

NO environment?

\begin{tabular}{|l|l|} 
YES & $\begin{array}{l}\text { Box 14 } \\
\text { Can institutional controls be } \\
\text { maintained during the flushing } \\
\text { period and is natural flushing and } \\
\text { active ground water remediation } \\
\text { protective of human health and the } \\
\text { environment? }\end{array}$ \\
\hline
\end{tabular}

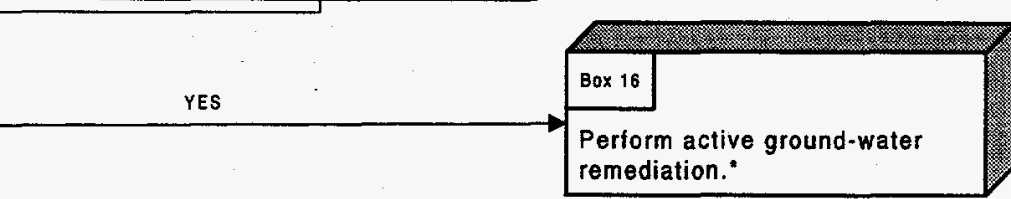

- Stragegy will be reevaluated if conditions change or if monitoring indicates that EPA standards will not be met

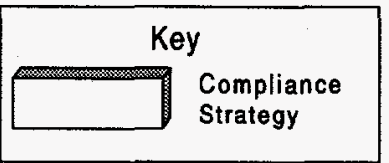

Figure 1. Proposed Action 


\subsubsection{Hydrogeologic Setting}

Ground water at the Spook site is in the upper and lower sandstone units of the Tertiary Wasatch Formation under unconfined and confined conditions, respectively (Figure 2.). Depths to the water table in the upper sandstone unit (uppermost aquifer) range from 40 to $120 \mathrm{ft}(12$ to $37 \mathrm{~m}$ ) below the ground surface, with a saturated thickness of approximately $20 \mathrm{ft}(6 \mathrm{~m})$. The upper and lower sandstone units are separated by an aquitard consisting of a thick, laterally extensive silty-shale unit (middle shale unit). There is no apparent hydraulic interconnection between the two sandstone units. Ground water in the upper sandstone unit is recharged by infiltration of precipitation and seepage from intermittent streams. During uranium milling operations in the 1960 s, processing solutions were released inadvertently into the upper sandstone unit.

Ground water in the upper sandstone unit flows predominantly northeast, under an average horizontal hydraulic gradient of 0.005 foot per feet $(\mathrm{ft} / \mathrm{ft})$. The average transmissivity of the upper sandstone unit is 225 square feet per day (2.42 square centimeters [cm] per second) and the average hydraulic conductivity is $15 \mathrm{ft}$ per day $\left(5.3 \times 10^{-3} \mathrm{~cm}\right.$ per second). The average linear ground-water velocity in the upper sandstone unit is $0.4 \mathrm{ft}$ per day $\left(1.3 \times 10^{-4} \mathrm{~cm}\right.$ per second), based on the above hydraulic conductivity, an average hydraulic gradient of $0.005 \mathrm{ft} / \mathrm{ft}$, and an estimated effective porosity of 0.2 (DOE 1995).

\subsubsection{Ground-Water Quality}

Background ground-water quality in the site vicinity is affected by elevated levels of naturally occurring uranium mineralization in the upper sandstone unit (Figure 2). These elevated levels existed prior to uranium processing activities at the site. Background ground-water quality was determined by assessing regional ground-water conditions within the upper sandstone unit and conditions in downgradient monitoring wells that were not impacted by uranium processing activities (Table 1) (DOE 1995).

The extent of ground-water contamination as a result of uranium processing activities (herein referred to as plume) was determined by evaluating nitrate concentrations (a residue of nitric acid used in uranium processing) in the ground water. Nitrate concentrations in ground water in excess of 13 milligrams per liter $(\mathrm{mg} / \mathrm{L})$ delineate the plume, which extends approximately $2,500 \mathrm{ft}(800 \mathrm{~m})$ downgradient from the site (Figure 2).

Comparisons of background and plume ground-water quality data in the upper sandstone unit indicate that concentrations of several constituents in the plume (chromium, nitrate, selenium, uranium, and radium-226 and -228) exceed background and are above maximum concentration limits (Table 1). Naturally occurring (ambient) concentrations of uranium and selenium in ground water in the upper sandstone beneath and downgradient from the site exceed the EPA maximum concentration limits of 0.044 and 0.01 milligrams per liter $(\mathrm{mg} / \mathrm{L})$, respectively. Contamination is restricted to the upper sandstone unit, which is underlain by a continuous shale aquitard (the middle shale unit). Because of the demonstrated lack of hydraulic interconnection with the upper sandstone unit (DOE 1995), ground water in the lower sandstone unit could not be contaminated as a result of uranium processing operations at this site.

\subsection{Ecological Communities}

The climate in the area of the Spook site is semiarid and cool with moderate humidity, abundant sunshine, and large daily and seasonal temperature ranges. The maximum summer air temperature is generally 70 to $80^{\circ} \mathrm{F}\left(21\right.$ to $\left.27^{\circ} \mathrm{C}\right)$ while the winter minimum is typically 7 to $11^{\circ} \mathrm{F}\left(-14\right.$ to $\left.-12^{\circ} \mathrm{C}\right)$. The average annual precipitation (measured in Casper, Wyoming) is about 11 inches $(28 \mathrm{~cm})$. 


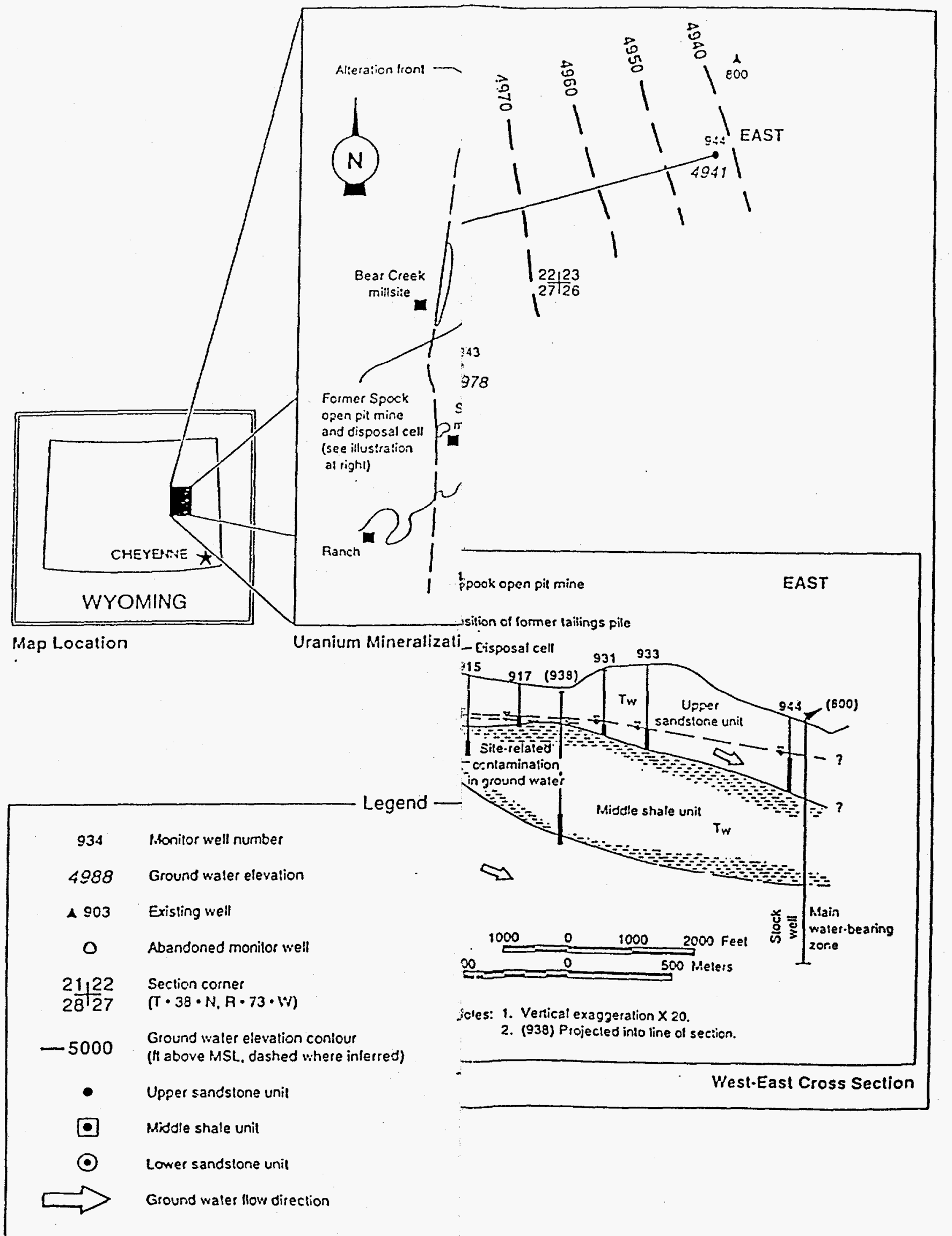




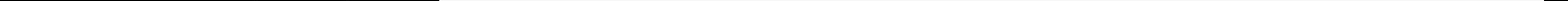




\begin{tabular}{|c|c|c|c|c|c|c|c|c|c|}
\hline \multirow[b]{2}{*}{ Constituent } & \multirow{2}{*}{$\begin{array}{c}\text { Ground Water } \\
\text { Contaminated }^{a} \\
\text { (median) }\end{array}$} & \multirow{2}{*}{$\begin{array}{c}\text { Background }^{b} \\
\text { (median) }\end{array}$} & \multirow[b]{2}{*}{$\mathrm{MCL}$} & \multicolumn{2}{|c|}{$\begin{array}{c}\text { Aquatic Life } \\
\text { Criteriac }^{c}\end{array}$} & \multirow{2}{*}{$\begin{array}{l}\text { Terrestrial Plant } \\
\text { Benchmarks }^{d}\end{array}$} & \multirow{2}{*}{$\begin{array}{c}\text { Terrestrial } \\
\text { Wildlife } \\
\text { Benchmarks }^{e}\end{array}$} & \multirow{2}{*}{$\begin{array}{c}\text { Irrigation } \\
\text { Water } \\
\text { Guidellne }\end{array}$} & \multirow{2}{*}{$\begin{array}{c}\text { Livestock } \\
\text { Water } \\
\text { Guideline }\end{array}$} \\
\hline & & & & Acute & Chronic & & & & \\
\hline Ammonium & 98 & $<0.1$ & - & - & - & - & - & - & - \\
\hline Antimony & 0.02 & $<0.003$ & - & - & - & - & 0.462 & - & - \\
\hline Arsenic & 0.012 & $<0.01$ & 0.05 & 0.36 & 0.19 & 0.001 & 0.465 & 0.1 & 0.2 \\
\hline Barium & $<0.06$ & $<0.10$ & 1.0 & - & - & - & 45.2 & - & - \\
\hline Chromium & 0.15 & 0.06 & 0.05 & 0.016 & 0.011 & 0.05 & 27.3 & 0.1 & 0.05 \\
\hline Manganese & 15 & 0.02 & - & - & 1.0 & 4 & 731 & 0.2 & - \\
\hline Molybdenum & 0.07 & 0.01 & 0.10 & & & 0.5 & - & & \\
\hline $\begin{array}{l}\text { Nitrate (as } \\
\mathrm{NO}_{3} \text { ) }\end{array}$ & 350 & 4.0 & 44 & & & - & 5,665 & - & - \\
\hline $\begin{array}{l}\text { Radium-226, } \\
-228(p \mathrm{C} / L)\end{array}$ & 44 & 2.2 & 5.0 & - & - & - & - & 5 & 5 \\
\hline Selenium & 0.96 & 0.39 & 0.01 & & & 0.7 & 0.28 & 0.02 & 0.05 \\
\hline Silver & 0.03 & 0.01 & 0.05 & & - & 0.1 & - & - & - \\
\hline Sulfate & 2,940 & 159 & - & - & - & - & - & 200 & 3,000 \\
\hline $\begin{array}{l}\text { Total } \\
\text { dissolved } \\
\text { solids }\end{array}$ & 4,970 & 500 & - & - & - & - & - & 2,000 & 5,000 \\
\hline Uranium & 0.80 & 2.0 & 0.044 & - & - & 40 & 11.08 & 5.0 & 5.0 \\
\hline
\end{tabular}

a Based on data from DOE monitoring wells SPK $-01-0920,-0930,-0935$, and -0940 (see Figure 1 for well locations).

${ }^{b}$ Based on data from DOE monitoring wells SPK-01-0918, -0925, -0931, -0943, and -0944 (see Figure 1 for well locations).

CFrom Wyoming Department of Environmental Quality (WDEQ) 1990.

From Opresko et al. 1994; benchmarks for white-footed mouse.

EFrom Will and Suter 1994.

FFrom WDEQ 1993.

Notes:

All data in milligrams per liter except as noted.

2. Median represents 50 th percentile of the pooled data from the wells in each category.

3. Dash indicates value is not available. 
The Spook site is an area of flat to rolling topography, between 5,030 and $5,160 \mathrm{ft}(1,530$ and $1,570 \mathrm{~m})$ above mean sea level. Predominant vegetation in the area is sagebrush with grass ground cover. Stands of large cottonwoods grow near the Dry Fork of the Cheyenne River, the water body nearest the site. Typically, the Dry Fork has extended periods with no flowing surface water. During field observations in August 1986, most of the riverbed was dry and grass was being mowed for hay. Occasional pools and wet depressions were noted, and cattails, soft-stemmed bulrush, wild mint, and sedges were common in these areas (Technical Assistance Contractor 1986). This vegetation indicates that even during dry periods, water in the shallow alluvium of the Dry Fork is relatively close to the surface, if not expressing onto the surface (DOE 1995).

Before surface remedial action, standing water occurred temporarily in the bottom of the Spook pit and in ponds west and south of the pit. A few cottonwoods in the bottom of the pit and near the temporary ponds used these water sources. After surface remediation was completed, the Spook pit was filled and the temporary ponds were excavated, filled, and recontoured. The cottonwoods near the former acid pond were still alive in 1994 and they may be accessing water from the natural drainage that leads into the pond.

\subsection{Land Use/Population}

The Spook site is located in a remote area, far from any large population centers. The nearest residence is $1.4 \mathrm{mi}(2.3 \mathrm{~km})$ southwest of the Spook site. Approximately 10 residents live within a 3-mi- $(5-\mathrm{km})$ radius of the site. The Converse County Planning Commissioner and local ranchers indicate that the large ranches near the site have been owned and operated by successive generations of the families currently in residence; this pattern is expected to continue. Thus, the current population density in the area is low and likely will remain low in the future (DOE 1990).

As agent for the United States of America, the State of Wyoming acquired title to a 13.5-acre(5.5-hectare) area containing the mill tailings disposal cell. DOE controls the subsurface mineral rights below the site. The land near the site, including the land overlying the ground-water plume, is privately. owned by two individuals who raise sheep and cattle. Consistent with ranching, this area contains numerous stock watering ponds. The water source for all ponds investigated was determined to be surface runoff or aquifers below the upper sandstone unit (DOE 1989). Some hay production takes place along the Dry Fork. Uranium mining occurred extensively in this area, and there has been some oil and gas development.

\subsection{Environmental Impacts}

Section 4.0 of the PEIS assessed the programmatic impacts of the proposed action for the Spook site and various compliance strategies. This section focuses on assessing the environmental impacts of the proposed action at the Spook site, considering both current and reasonably projected uses of the affected ground water. EPA regulations require that supplemental standards protect human health and the environment and, if the ground water is determined to be limited use, current and reasonably projected uses of the affected ground water must be preserved (40 CFR 192.22[d]). Environmental justice issues were considered and it was determined that disproportionately high and adverse human health or environmental effect on minority or low-income population would not occur.

\subsection{Impacts From Proposed Action}

\subsubsection{Human Health}

Appendix B of the PEIS details the methods used to assess the human health risks at the Spook site. A screening-level human risk analysis was performed on the basis of background ground-water quality data 
from the altered upper sandstone unit (DOE 1995). This analysis determined there are no known current exposure pathways for ground water from the upper sandstone unit near the site because the ground water is not used as a drinking-water source or for any other purposes. Historical and projected land uses for this area indicate population growth and ranching activities will not increase to the extent that use of groundwater from the upper sandstone would be required.

Livestock watering and irrigation could produce a secondary exposure pathway to humans. As the Spook ground-water plume disperses areally, it will add to the existing elevated levels of naturally occurring contamination. The contaminated ground water exceeds the livestock watering guidelines for chromium, selenium, and radium-226 and -228 . The naturally occurring concentrations of contamination in the upper sandstone unit, independent of plume contamination, already exceed the livestock watering guideline for selenium (Table 1). However, the water source for all livestock ponds investigated is surface runoff or aquifers below the upper sandstone unit (DOE 1989).

Because there are no current or foreseeable future exposure pathways from the ground water in the uppermost aquifer near the Spook site, the ground water does not threaten human health. Therefore, if the proposed action is implemented, no impacts to human health are expected from the contaminated ground water in the upper sandstone unit aquifer.

\subsubsection{Surface Water}

Field observations in the area of the Spook site indicate that ground water from the upper sandstone unit does not discharge to the surface (DOE 1995). Ground water in the upper sandstone unit is more than $100 \mathrm{ft} \mathrm{(30} \mathrm{m)} \mathrm{deep} \mathrm{in} \mathrm{the} \mathrm{site} \mathrm{area,} \mathrm{which} \mathrm{prevents} \mathrm{the} \mathrm{ground} \mathrm{water} \mathrm{from} \mathrm{surfacing} \mathrm{(DOE} \mathrm{1995).} \mathrm{Some} \mathrm{of}$ the contaminated ground water flows toward the Dry Fork of the Cheyenne River. The depth of ground water in the upper sandstone unit beneath the Dry Fork has not been determined, but the Spook SOWP indicates that the depth to water in this unit could be as little as $25 \mathrm{ft}(7.6 \mathrm{~m})$ below the river alluvium (DOE 1995). Given that ground water in the upper sandstone unit is unconfined and there is no upward hydraulic gradient, there is no evidence that ground water from the upper sandstone unit is discharging into the Dry Fork. Water in the shallow alluvium of the Dry Fork likely recharges the upper sandstone unit.

One surface water sample was collected from the Dry Fork near the ranch more than $1 \mathrm{mi}(1.6 \mathrm{~km})$ southwest of the Spook site. No constituents in this water exceeded the EPA maximum concentration limits. However, this sample is of limited value because it was taken outside the alteration zone (Figure 2). Surface water samples were not collected from the Dry Fork inside the alteration zone because ground water from the upper sandstone unit does not discharge into the Dry Fork.

\subsubsection{Ground Water}

The impact of the proposed action to ground water in the upper aquifer in the area of the Spook site would minimally degrade the naturally occurring poor ground-water quality as the plume moves from the site. Ground water in other deeper aquifers would not be affected.

\subsubsection{Ecological Communities}

If contaminated ground water were to affect the ecological communities at or near the Spook site, it would be through surface expression or through plant root uptake. There is no evidence that contaminated ground water in the upper sandstone unit is discharging into the environment in the site area. Because the projected depth to the ground water is below the base of the shallow alluvium in the Dry Fork, ground water from the upper sandstone unit is not discharging into the Dry Fork of the Cheyenne River. 
Because ground water is about $100 \mathrm{ft}(30 \mathrm{~m})$ below land surface in the site area, plants growing around the site have not sent roots into the ground water. A small group of cottonwoods grows in the area of the former acid pond. This pond and the associated contaminated soil were cleaned up during surface remediation in 1989, but these trees were still alive in 1994. The cottonwoods are obtaining underground water because they cannot survive on the annual precipitation alone. The depth to ground water in the upper sandstone unit in this area is much deeper than the rooting depth of this species. These trees likely rooted in an area of localized alluvial ground water that may be associated with the ephemeral drainage area (Dry Fork). Therefore, it is not likely that plant species were contaminated from processing activities at the site.

Because there is no known surface expression of ground water and no plant uptake of contaminated ground water, there are no impacts to threatened and endangered species, sensitive habitats, or any other ecological resource. However, using ground water from the plume or from the altered background water to create a wildlife habitat such as ponds or wetlands would not be advisable because ground water concentrations of both selenium and silver exceed the aquatic life criteria (Table 1). Concentrations in the contaminated and in the background ground water exceed the acute criteria for selenium by 48 and 20 times, respectively, and the acute silver criteria by 7 and 2 times, respectively. These concentrations would be highly toxic to wildlife. For example, a study at a national wildlife refuge in California showed that selenium entering the refuge at much lower concentrations $(0.122 \mathrm{mg} / \mathrm{L})$ than occur in the upper sandstone unit at the Spook site resulted in almost complete reproductive failure and mortality in marsh birds (Ohlendorf 1989).

\subsubsection{Land Use/Population}

The proposed action would not result in adverse impacts to land use or populations in the area of the Spook site because there are no current or planned uses of ground water from the upper sandstone unit.

\subsection{Impacts of the No-Action Alternative}

DOE previously characterized the site and monitoring data were collected during the surface remediation. No additional ground water data will be collected for the site. Under both the proposed action and the no-action alternative, remediation activities would not take place at or near the site. Therefore, the impacts to human health, surface water, ground water, biological communities, and land use would be the same under the no-action alternative as under the proposed action.

Under the no-action alternative, however, certain legal requirements would not be met. These requirements include NRC concurrence on the adequacy and protectiveness of DOE actions, and public, State, and NRC review and participation in the DOE decision.

\subsection{Agencies Consulted}

Agencies were not consulted or contacted during the preparation of this environmental assessment; however, during preparation of the Environmental Assessment of Remedial Action at the Spook Uranium Mill Tailings Site, Spook, Wyoming (DOE 1989) and the PEIS, appropriate agencies were contacted. The information provided in this assessment tiers to the relevance of previous information provided by those agencies listed in the documents referenced above. 


\subsection{References}

Ohlendorf, H. M., 1989. "Bioaccumulation and Effects of Selenium Wildlife," in Selenium Agriculture and the Environment, Special Publication No. 23, Soil Science Society of America, Madison, Wisconsin.

Opresko, D. M., B. E. Sample, and G. W. Suter, 1994. Toxicological Benchmarks for Wildlife: 1994 Revision, ES/ER/TM-86/RI, U.S. Department of Energy, Oak Ridge National Laboratory, Oak Ridge, Tennessee.

Technical Assistance Contractor, 1986. Unpublished field reports, Spook, Wyoming, UMTRA Project Site, prepared by the Technical Assistance Contractor for the U.S. Department of Energy, UPDCC File Location No. 15.14.1, UMTRA Project Office, Albuquerque Operations Office, Albuquerque, New Mexico.

\section{U.S. Code of Federal Regulations}

Title 10, Energy, Part 1021, "National Environmental Policy Act; Implementing Procedures and Guidelines Revocation; Final Rule and Notice."

Title 40, Protection of Environment, Part 192, "Health and Environmental Protection Standards for Uranium and Thorium Mill Tailings."

U.S. Department of Energy, 1989. Environmental Assessment of Remedial Action at the Spook Uranium Mill Tailings Site, Spook, Wyoming, final, DOE/EA-0345, U.S. Department of Energy, UMTRA Project Office, Albuquerque Operations Office, Albuquerque, New Mexico, April 1989.

- 1990. Remedial Action Plan and Site Conceptual Design for Stabilization of the Inactive Uranium Mill Tailings Site at Spook, Wyoming, UMTRA-DOE/AL-050515.0000, U.S. Department of Energy, UMTRA Project Office, Albuquerque Operations Office, Albuquerque, New Mexico.

1995. Site Observational Work Plan for the UMTRA Project Site at Spook, Wyoming, Rev. 0, UMTRA-DOE-AL-62350-156, prepared by Jacobs Engineering Group Inc., Albuquerque, New Mexico, for the U.S. Department of Energy, UMTRA Project Office, Albuquerque Operations Office, Albuquerque, New Mexico.

1996. Final Programmatic Environmental Impact Statement for the Uranium Mill Tailings Remedial Action Ground Water Project, DOE/EIS-0198, Rev. 7, prepared by Jacobs Engineering Group Inc., Albuquerque, New Mexico, for the U.S. Department of Energy, Grand Junction Office, Grand Junction, Colorado.

U.S. Nuclear Regulatory Commission, 1996. Letter regarding Site Observational Work Plan for the UMTRA Project Site at Spook, Wyoming from Joseph H. Holonich, Chief, Uranium Recovery Branch Division of Waste Management Office of Nuclear Material Safety and Safeguard, Washington, D.C., to Ray Plieness, U.S. Department of Energy, Grand Junction Office, Grand Junction, Colorado, April 26.

Will, M. E., and G. W. Suter, 1994. Toxicological Benchmarks for Screening Potential Contaminants of Concern for Effects on Terrestrial Plants: 1994 Revision, ES/ER/TM-85/R1, Oak Ridge National Laboratory, Oak Ridge, Tennessee.

Wyoming Department of Environmental Quality, 1990. Water Quality Rules and Regulations, Chapter I, "Quality Standards for Wyoming Surface Waters," Cheyenne, Wyoming. 
Wyoming Department of Environmental Quality, 1993. Water Quality Rules and Regulations, Chapter VIII, "Quality Standards for Wyoming Ground Waters," Cheyenne, Wyoming. 
Appendix A 
This page intentionally blank 


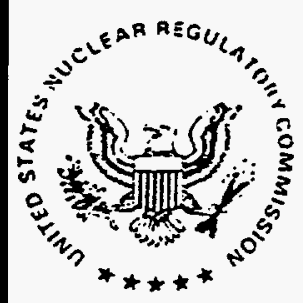

UNITED STAT

NUCLEAR REGULATORY COMMISSION PECFIITA RO:

WASHINGTON, D.C. 20555-0001

April 23, 1996

Mr. Ray Plieness

U.S. Department of Energy

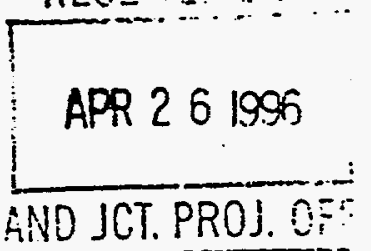

Grand Junction Project Office

P.0. Box 2567

Grand Junction, CO 81502-2567

SUBJECT: SITE OBSERVATIONAL HORK PLAN FOR THE SPOOK URANIUM MILL TAILINGS REMEDIAL ACTION PROJECT SITE

Dear Mr. Plieness:

The U.S. Nuclear Regulatory Commission staff has reviewed the U.S. Department of Energy's (DOE) Site Observational Work Plan (SOWP) for the Spook, Wyoming Uranium Mill Tailings Remedial Action Project processing site, which was transmitted to the NRC by DOE's letter daied August 14, 1995. The groundwater compliance strategy proposed in the SOWP $i=$ to perform no further remediation at the site, based on the application of supplemental standards to water contained in the uppermost aquifer. The basis for this strategy is that groundwater in the uppermost aquifer is neither a current nor potential source of drinking water because of widespread ambient contamination not related to uranium milling activity, and that the uppermost aquifer does not discharge groundwater to deeper aquifers or to the surface. In concurring on the Spook Site Remedial Action Plan (RAP) for surface reclamation, NRC staff agreed with DOE's characterization of groundwater conditions at the site and concluded that monitoring the uppermost aquifer is unnecessary. Therefore, DOE's decision not to perform groundwater remediation at the site is consistent with the RAP. Based on its review, NRC staff has no comments on the Spook SOWP.

If you have any questions, please contact the NRC Project Manager, Janet Lambert at (301) 415-6710.

Sincerely,

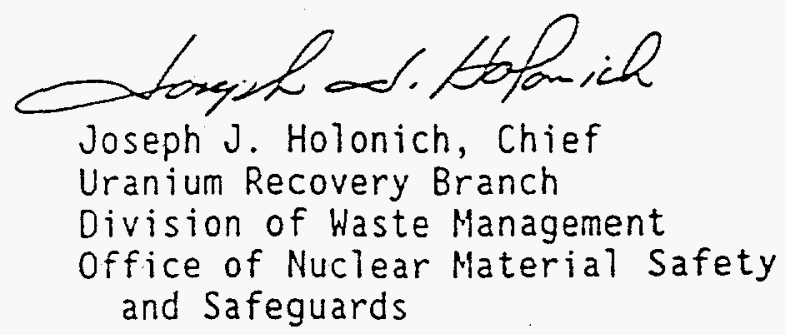

cc: J. Pape, DOE AIb

S. Hamp, DOE Alb

J. Virgona, DOE GJPO

D. Metzler, DOE GJPO 


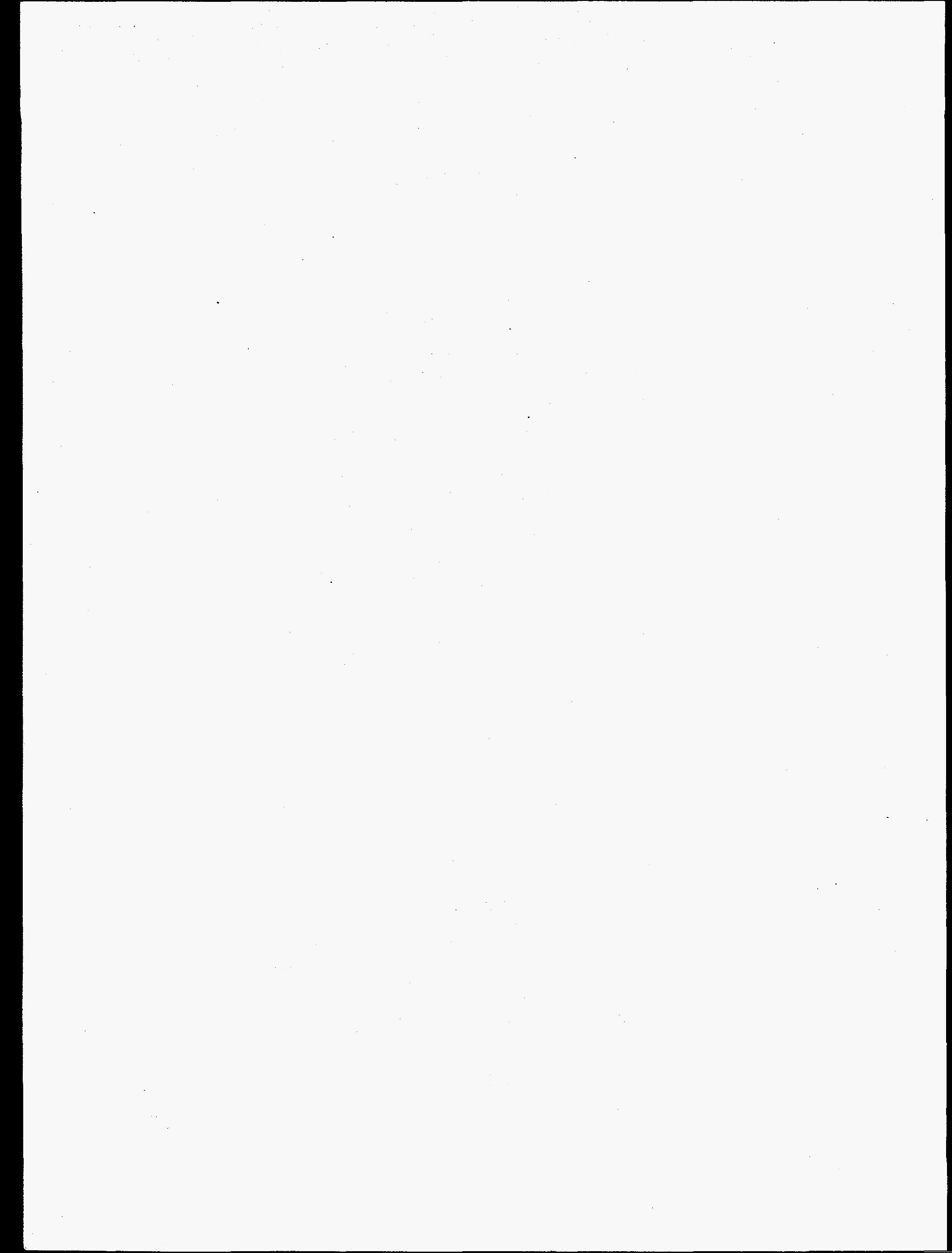




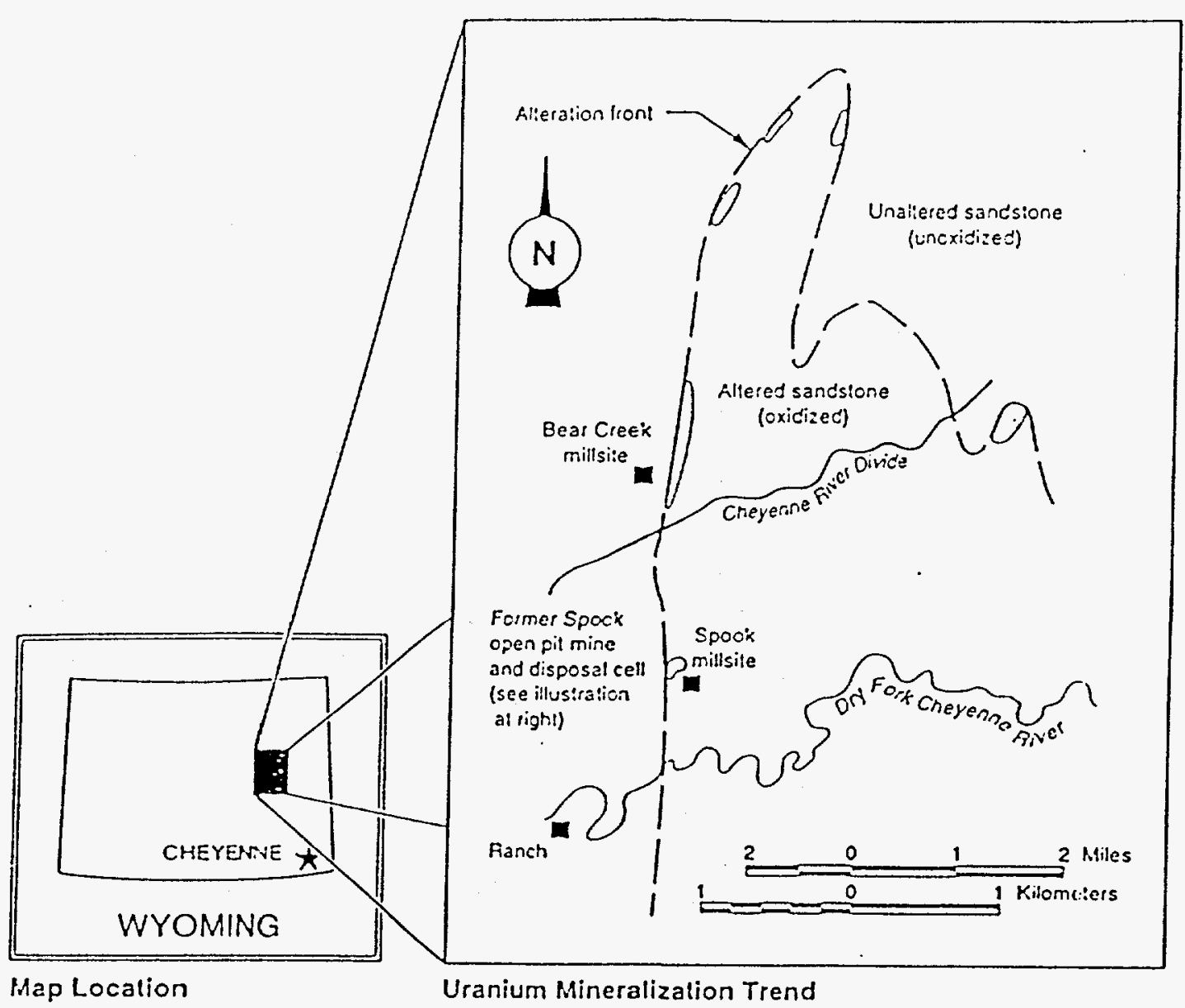

\section{Legend}

\begin{tabular}{|c|c|}
\hline 934 & 1.fonitor well number \\
\hline 4988 & Ground water elevation \\
\hline 1903 & Existing well \\
\hline 0 & Abandoned monitor well \\
\hline $\begin{array}{l}21 / 22 \\
28127\end{array}$ & $\begin{array}{l}\text { Section coiner } \\
(T \cdot 38 \cdot N, R \cdot 73 \cdot(\mathrm{V})\end{array}$ \\
\hline 5000 & $\begin{array}{l}\text { Ground water elevation conlour } \\
\text { (th above MSL. dashed where inlerred) }\end{array}$ \\
\hline
\end{tabular}

- Upper sandstone unit

- Middle shale unit

- Lower sandslone unit

Ground water llow direction

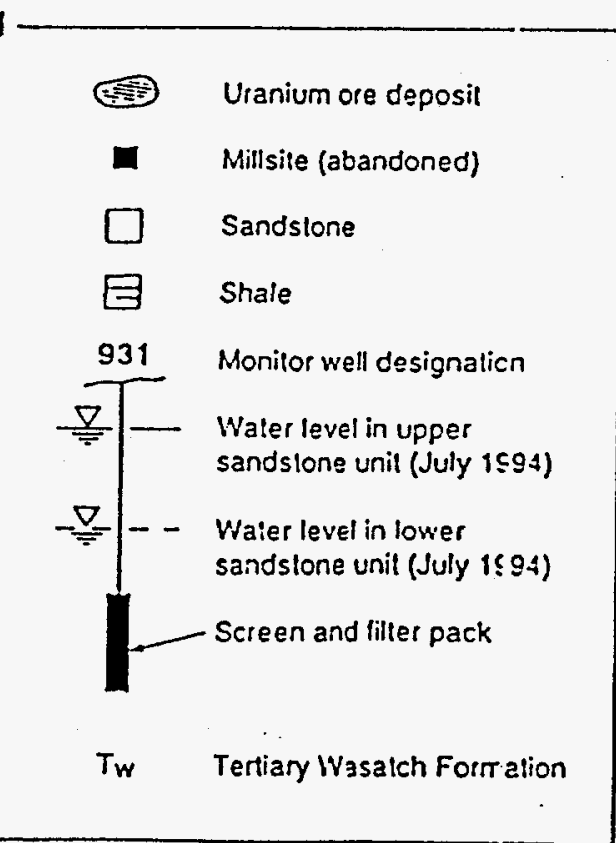

Figure 2. Location and Hydro 